\title{
Spectrophotometric determination of thymol in pharmaceuticals with Gibb's reagent
}

\author{
Usra. I. S. Al-Neaimy \\ Department of physiology / College of Vet. Medicine \\ Mosul University
}

Received

r r / 00/ 200^
Accepted

$01 / 12$ / 2008

\begin{abstract}
الخلاصة
تم وصف طريقة طيفية بسطة وسريعة لتقير الثايمول بهيئته النقية وفي المستحضرات

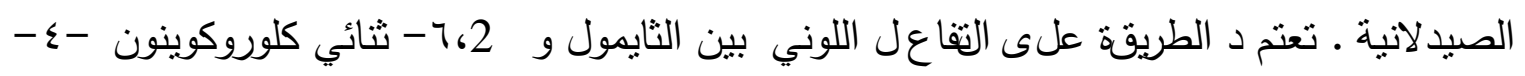

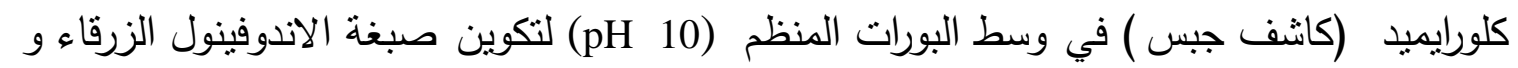

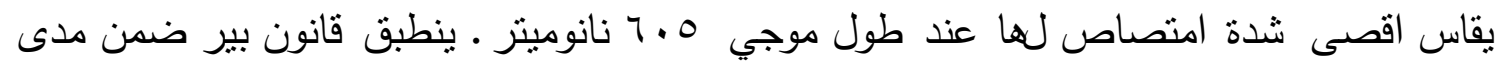

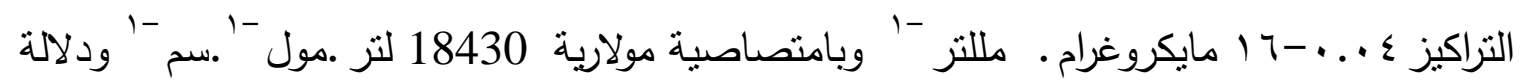

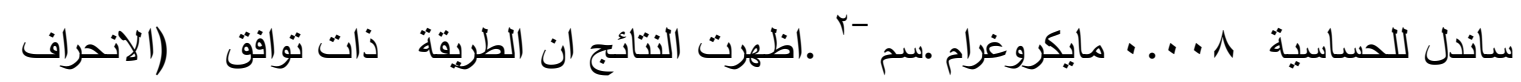

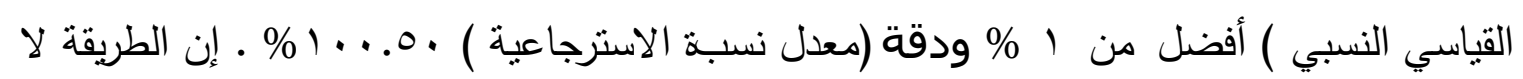
تحتاج الى السيطرة على درجة الحرارة او الاستخلاص بالمذيب. تم تطبيق الطريقة بنجاح في تقدير الثايمول في غسولات الفم وقورنت النتائج مع طريقة ع -امينو انتي بليرين القياسية.
\end{abstract}

\begin{abstract}
A simple and rapid spectrophotometric method for the determination of thymol in pure form and in pharmaceutical preparations is described . The method is based on the color reaction between thymol and 2,6dichloroquinone-4- chloroimide (Gibb's reagent) in borate buffer medium ( $\mathrm{pH}$ 10) to form a blue indophenol dye with maximum absorption $605 \mathrm{~nm}$. Beer's law is obeyed over the concentration range of $0.04-16 \mu \mathrm{g} . \mathrm{ml}^{-1}$ with a molar absorptivity of $184301 . \mathrm{mol} . \mathrm{cm}^{-1}$ and sandell sensitivity index of 0.008
\end{abstract}


$\mu$ g.cm. The results obtained were both precise (RSD) better than $1 \%$ and accurate (average recovery) 100.50\%. The method does not resort to temperature control or to solvent extraction. The method has been applied further, successfully to the determination of thymol in mouthwashes and the results obtained are comparable with those given by the standard 4aminoantipyrine method.

\section{Introduction}

Thymol is a component of thyme essential oil, which has been reported to possess interesting antimicrobial effects on various microorganisms, hence thymol is used in the case of female urogenital infections, bacterial vaginosis, urinary tract infections and vaginitis (1). Thymol has also many uses, including perfumes, food flavoring, mouthwashes, cosmetics and also as stabilizer to several therapeutic agents including halothane $(2,3)$.

Thymol has been determined spectrophotometrically via oxidative coupling with $\mathrm{N}, \mathrm{N}$-diethylphenylenediamine in the presence of $\mathrm{N}$ bromosuccinamide in alkaline medium (4) and p-phenylenediamine in the presence of sodium metaperiodate in alkaline medium(5) or by coupling with diazotized 2,4,6-trimethylaniline reagent in borate buffer solution (6) and diazotized p-nitroaniline in basic medium (7), in addition of its spectrophotometric determination by reacting with sodium nitroprusside and hydroxylamine hydrochloride in phosphate buffer solution (8). Also, several analytical methods have been reported for the estimation of thymol including high-performance liquid chromatography (9) and gas chromatography $(10,11)$.

Gibb's reagent (2,6-dichloroquinone-4- chloroimide) has numerous applications as analytical reagent .It has been used for the determination of hallogenated derivatives of 8-hydroxyquinoline (12), some adrenergic drugs (13), aminosalicylate sodium (14), salbutamol (15).

The aim of this work is to develop a new simple spectrophotometric procedure for accurate and rapid analysis of thymol using 2,6dichloroquinone-4- chloroimide as a coloring reagent.

\section{Apparatus}

Absorption spectra and absorbances were measured in a Shimadzu UV 150-02 double beam spectrophotometer using 1-cm glass cells.

\section{Reagents}

All chemicals used were of analytical reagent grade. 


\section{Thymol solution, $100 \mu \mathrm{g} . \mathrm{ml}^{-1}$}

This solution was prepared by dissolving $0.01 \mathrm{~g}$ of thymol (BDH) in $5 \mathrm{ml}$ of absolute ethanol and then the volume was completed to $100 \mathrm{ml}$ with distilled water. The solution was stable at least for two weeks.

\section{Gibb's reagent, $5 \times 10^{-3} \mathrm{M}$}

The solution was prepared freshly by dissolving $0.1052 \mathrm{~g}$ (Fluka) of 2,6-dichloroquinone -4- chloroimide (DCQ) in ethanol and diluted to $100 \mathrm{ml}$ in volumetric flask with the same solvent and kept in a dark bottle.

\section{Borate buffer solution (pH 10)}

This solution was prepared by mixing $50 \mathrm{ml}$ of $0.025 \mathrm{M}$ $\mathrm{Na}_{2} \mathrm{~B}_{4} \mathrm{O}_{7} .10 \mathrm{H}_{2} \mathrm{O}$ with $18.3 \mathrm{ml}$ of $0.1 \mathrm{M}$ sodium hydroxide then the volume was completed to $100 \mathrm{ml}$ with distilled water.

\section{Procedure for calibration}

To a series of $25 \mathrm{ml}$ calibration flasks, increasing volumes of thymol working standard solution were transferred to cover the range

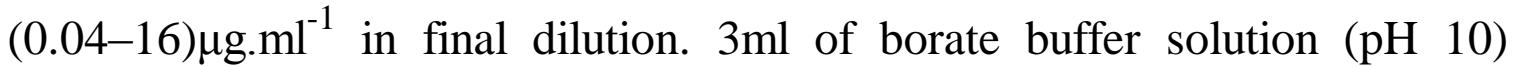
followed by $3 \mathrm{ml}$ of DCQ reagent solution were added. The mixture was well mixed, allowed to stand for $5 \mathrm{~min}$ at room temperature and the absorbance was measured at $605 \mathrm{~nm}$. A reagent blank was run simultaneously.

\section{Assay procedure for a drug}

\section{Determination of thymol in listerine antiseptic original mouthwash :}

Thymol was prepared in the concentration $256 \mu \mathrm{g} \cdot \mathrm{ml}^{-1}$ by diluting $20 \mathrm{ml}$ of Listerine (from Warner - Lambert Pharmaceutical Co. which was certified to contain $64 \mathrm{mg}$ thymol/100ml) to $50 \mathrm{ml}$ with distilled water and $100 \mu \mathrm{g} . \mathrm{ml}^{-1}$ of thymol solution was prepared from this above solution, then different volumes used from this solution containing the concentration range $0.04-16 \mu \mathrm{g} \cdot \mathrm{ml}^{-1}$. After that the calibration procedure described above was carried out.

\section{Determination of thymol in septica effervescent tablets :}

Septica is effervescent tablets from avicenna labs. Damascus. Each tablet contains $4 \mathrm{mg}$ thymol. Twenty tablets were weighed, powdered, mixed and an amount of the powder equivalent to five tablets was transferred into $100 \mathrm{ml}$ calibrated flask, dissolved in distilled water and the volume was completed with the same solvent, then $100 \mu \mathrm{g} \cdot \mathrm{ml}^{-1}$ was prepared from this above solution and the calibration procedure was carried out. 


\section{Results and discussion}

\section{Absorption spectra}

Thymol was reacted with DCQ in basic medium producing a blue colored product with maximum absorption at $605 \mathrm{~nm}$, while the reagent blank shows no absorption at this wavelength (Fig 1).

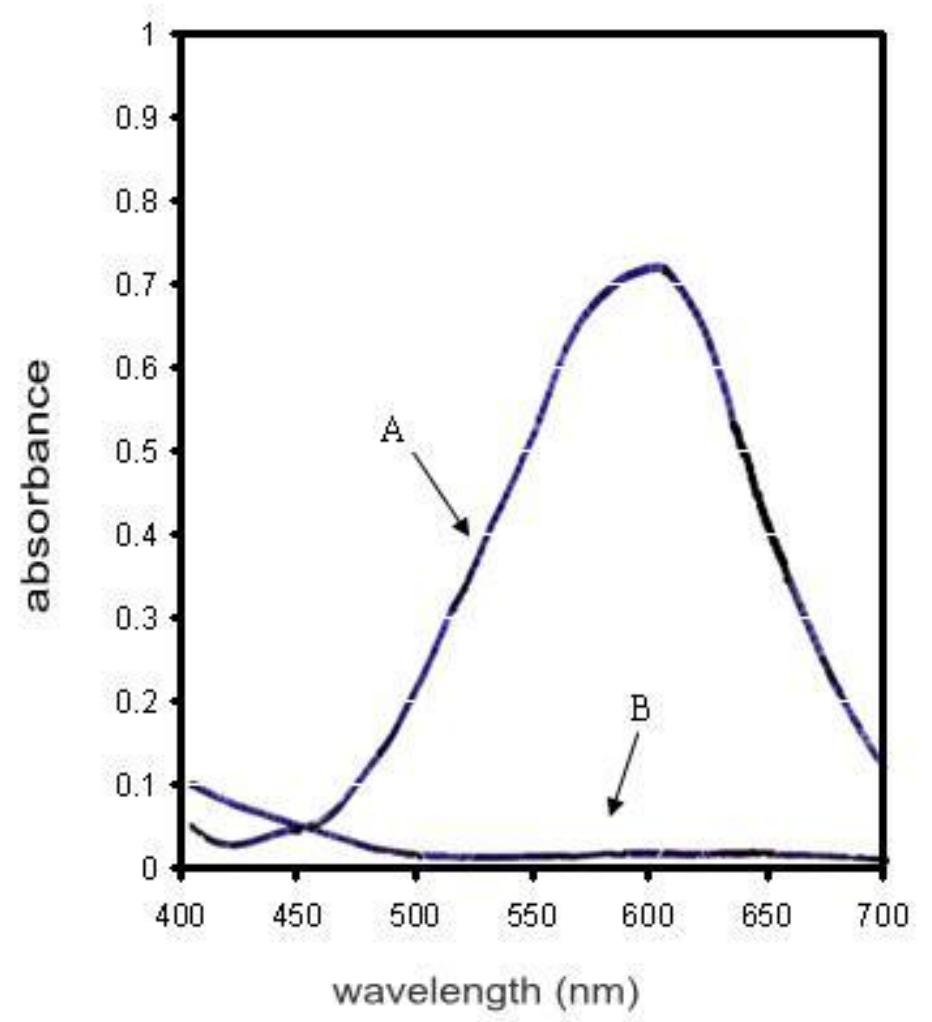

Fig (1) : Absorption spectra :

A : Thymol $\left(6 \mu \mathrm{g} \cdot \mathrm{ml}^{-1}\right)-\mathrm{DCQ}\left(5 \times 10^{-3}\right)$ product versus reagent blank.

B : Reagent blank versus D.W.

\section{Effect of pH and buffers}

The effect of $\mathrm{pH}$ on the sensitivity of the colored reaction product was investigated in the range of 4-13. The results obtained showed that the optimum $\mathrm{pH}$ value was 10 . Therefore different buffer solutions of $\mathrm{pH} 10$ were prepared. The results shown in Table 1 and 2 indicate that borate buffer solution gives clear blue color with maximum intensity and it was found that the optimum amount of borate buffer was $3 \mathrm{ml}$. 
Table (1): Effect of buffer solution on the absorbance

\begin{tabular}{|c|c|c|c|}
\hline Buffer solution pH 10 & Phosphate & Borate & Carbonate \\
\hline Absorbance & $\mathbf{0 . 4 8 5}$ & $\mathbf{0 . 5 1 6}$ & $\mathbf{0 . 4 4 3}$ \\
\hline
\end{tabular}

Table (2): Effect of borate buffer amount on the absorbance

\begin{tabular}{|c|c|c|c|c|c||}
\hline $\mathbf{p H}$ & $\mathbf{1}$ & $\mathbf{2}$ & $\mathbf{3}$ & $\mathbf{4}$ & $\mathbf{5}$ \\
\hline \hline Absorbance & $\mathbf{0 . 5 1 3}$ & $\mathbf{0 . 5 4 0}$ & $\mathbf{0 . 6 0 1}$ & $\mathbf{0 . 5 5 2}$ & $\mathbf{0 . 5 3 6}$ \\
\hline
\end{tabular}

\section{Effect of temperature and reaction time}

The reaction time was determined by following the color development at room temperature and in a thermostatically controlled water bath adjusted at 0,40 and $50 \mathrm{C}^{\circ}$. The absorbance was measured at $5 \mathrm{~min}$ intervals against reagent blank treated similarly. It was observed that the absorbance reached maximum after 5 min at room temperature and remained constant for at least 3 hours and the absorbance decreased slowly thereafter. Hence, room temperature and reaction time $(5 \mathrm{~min})$ were chosen for color development (Table 3) .

Table (3): Effect of temperature and reaction time

\begin{tabular}{||c||c|c|c|c|c|c|c|c|c|c|c||}
\hline \multicolumn{1}{|c|}{$\begin{array}{c}\text { Temp } \\
\left(C^{\circ}\right)\end{array}$} & \multicolumn{10}{|c||}{ Absorbance / min standing time } \\
\hline \hline 0 & 5 & 10 & 20 & 30 & 40 & 50 & 60 & 90 & 180 & 240 \\
\hline \hline 0 & - & 0.581 & 0.579 & 0.575 & 0.578 & 0.574 & 0.568 & 0.568 & 0.563 & 0.543 & 0.540 \\
\hline \begin{tabular}{c|c} 
Room \\
temp
\end{tabular} & 0.600 & 0.603 & 0.603 & 0.603 & 0.603 & 0.603 & 0.603 & 0.603 & 0.603 & 0.603 & 0.580 \\
\hline \hline 40 & - & 0.587 & 0.579 & 0.575 & 0.570 & 0.569 & 0.568 & 0.560 & 0.554 & 0.532 & 0.501 \\
\hline \hline 50 & - & 0.586 & 0.570 & 0.571 & 0.570 & 0.569 & 0.560 & 0.549 & 0.540 & 0.530 & 0.513 \\
\hline \hline
\end{tabular}

\section{Effect of 2,6-dichloroquinone-4-chlorimide (DCQ) concentration}

The effect of various DCQ concentrations on the absorbance of solution containing $6 \mu \mathrm{g} \cdot \mathrm{ml}^{-1}$ thymol was studied, it is evident that the absorbance increases with increasing DCQ concentration and reached maximum on using $3 \mathrm{ml}$ of $5 \times 10^{-3} \mathrm{M}$ DCQ . Therefore, this volume was used in all subsequent work (Table 4). 
Spectrophotometric determination of thymol in pharmaceuticals with ...

Table (4): Effect of DCQ concentration

\begin{tabular}{||c||c||c|c||c||c||}
\hline ml of DCQ solution $5 \times 10^{-3} \mathrm{M}$ & 1 & 2 & 3 & 4 & 5 \\
\hline \hline Absorbance & 0.539 & $\mathbf{0 . 6 0 2}$ & $\mathbf{0 . 7 2 9}$ & $\mathbf{0 . 5 7 3}$ & $\mathbf{0 . 5 5 1}$ \\
\hline
\end{tabular}

\section{Effect of surfactant}

The effect of different types of surfactants were used for the improvement of the absorption but the results shown in Table 5 confirm that there is no improvement in the absorption, therefore they were excluded.

Table (5): Effect of surfactant

\begin{tabular}{|l|c|}
\hline \multicolumn{1}{|c|}{ Surfactant* } & Absorbance \\
\hline \hline Cetyltrimethylammonium bromide $(0.1 \%)$ & 0.692 \\
\hline \hline Sodium dodecyl sulphate $(0.1 \%)$ & 0.686 \\
\hline \hline Triton X-100 $(1.0 \%)$ & 0.699 \\
\hline Without surfactant & 0.731 \\
\hline
\end{tabular}

$* 1 \mathrm{ml}$ of surfactant

\section{Analytical data}

Under the proposed experimental conditions linear relation between the absorbance and the concentration of thymol was observed over the concentration range $0.04-16 \mu \mathrm{g} \cdot \mathrm{ml}^{-1}$ (Fig 2) with a correlation coefficient of 0.9996 and intercept of 0.015. A negative deviation from Beer's law was observed above $16 \mu \mathrm{g} \cdot \mathrm{ml}^{-1}$ concentration of thymol .The molar absorptivity was $184301 . \mathrm{mol}^{-1} \mathrm{~cm}^{-1}$.

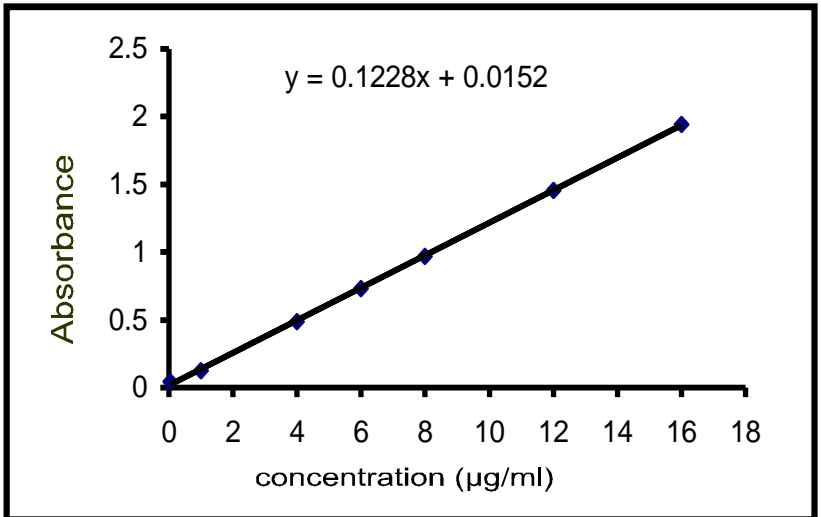

Fig (2): calibration graph of thymol 


\section{Accuracy and precision}

To determine the accuracy and precision of the calibration graph, thymol was determined at three different concentrations. The results shown in Table 6 indicate a satisfactory precision and accuracy.

Table (6): Accuracy and precision of proposed method

\begin{tabular}{||c||c|c||}
\hline Amount of thymol taken $\left(\boldsymbol{\mu g} \cdot \mathrm{ml}^{-1}\right)$ & Recovery $(\%)^{*}$ & Relative standard deviation $(\%)^{*}$ \\
\hline \hline 2 & 101.23 & $\mathbf{0 . 8 8}$ \\
\hline \hline 6 & 100.19 & 0.21 \\
\hline \hline 12 & 100.08 & 0.12 \\
\hline
\end{tabular}

* Average for six determinations

\section{Nature of product and reaction mechanism}

To establish the composition (ratio of thymol to DCQ reagent) of the blue indophenol dye formed, Job's method of continuous variations and mole-ratio method have been used. The resulting data show that 1:1 thymol to reagent are reacted and the color reaction does not require any oxidant (16). Therefore, the formation of the product may be illustrated as follows:<smiles>N=C1C=C(Cl)C(=O)C(Cl)=C1</smiles><smiles>Cc1ccc(C(C)C)c(O)c1</smiles><smiles>C=CC</smiles><smiles>C=C1C=C(Cl)C(=O)C(Cl)=C1</smiles><smiles>Cc1cc(O)c(C(C)C)cc1N=N</smiles>

The stability constant of the product was estimated and found to be $5 \times 10^{6} 1 . \mathrm{mol}^{-1}$.

\section{Effect of interferences}

In order to assess the possible analytical application of the proposed method, the effect of some common excipients usually present with drug in pharmaceutical formulation was studied by analyzing synthetic sample solution containing $100 \mu \mathrm{g}$ of thymol and (10-fold excess) of each excipient, none of these substances interfered seriously (Table 7).

Table (7) :Interference effect of excipients (1000 $\mu \mathrm{g})$ on the recovery of $100 \mu \mathrm{g} / 25$ $\mathrm{ml}$ of thymol

\begin{tabular}{|c|c|c|}
\hline & \begin{tabular}{|l|} 
Excipients \\
\end{tabular} & \begin{tabular}{|l|} 
Recovery \% \\
\end{tabular} \\
\hline & \begin{tabular}{|l|} 
Starch \\
\end{tabular} & \begin{tabular}{|l|}
102.56 \\
\end{tabular} \\
\hline & \begin{tabular}{|l} 
Glucose \\
\end{tabular} & 101.31 \\
\hline & Acacia & 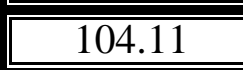 \\
\hline & \begin{tabular}{|l} 
Glycerol \\
\end{tabular} & 102.55 \\
\hline & \begin{tabular}{|l|} 
Arabic gun \\
\end{tabular} & 103.13 \\
\hline
\end{tabular}


The proposed method was applied to the determination of thymol in pharmaceutical formulations. Good recovery was obtained and the results compared with the standard 4- aminoantipyrine (17) (Table 8 and Table 9). The experimental t-test found to be 1.55 and 0.24 for listerine and septica, respectively. While the tabulated value is 2.776 at the $95 \%$ confidence limit for four degrees of freedom, which indicate that this method is reliable for application.

Table (8): Assay of thymol in mouthwash Listerine

\begin{tabular}{||c|c|c|c||}
\hline \multicolumn{2}{|c|}{ Present method } & \multicolumn{2}{c|}{ Standard method } \\
\hline \hline $\begin{array}{c}\text { Drug content } \\
\text { found* }(\mathrm{mg} / 100 \mathrm{ml})\end{array}$ & Recovery* $(\%)^{*}$ & $\begin{array}{c}\text { Drug content } \\
\text { found* }(\mathrm{mg} / 100 \mathrm{ml})\end{array}$ & Recovery* (\%) \\
\hline \hline 63.60 & 99.37 & 64.06 & 100.10 \\
\hline 65.50 & 102.34 & 65.41 & 102.20 \\
\hline 65.20 & 101.87 & 64.43 & 100.67 \\
\hline
\end{tabular}

Certified value $64 \mathrm{mg} / 100 \mathrm{ml}$

* Average for three determinations

Table (9): Assay of thymol in septica tablet

\begin{tabular}{||c|c|c|c||}
\hline \multicolumn{2}{|c|}{ Present method } & \multicolumn{2}{c||}{ Standard method } \\
\hline \hline $\begin{array}{c}\text { Drug content } \\
\text { found* }(\mathbf{m g})\end{array}$ & Recovery* $(\%)$ & $\begin{array}{c}\text { Drug content } \\
\text { found* }(\mathbf{m g})\end{array}$ & Recovery* (\%) \\
\hline \hline 4.07 & 101.75 & 4.03 & 100.75 \\
\hline 3.97 & 99.25 & 3.92 & 98.00 \\
\hline 4.02 & 100.50 & 4.08 & 102.00 \\
\hline
\end{tabular}

Certified value $4 \mathrm{mg}$

*Average for three determinations

\section{Comparison of methods}

Table 10 gives the comparison between the present method and another spectrophotometric method.

Table (10): comparison of the present method with other method 
Usra. I. S. Al-Neaimy

\begin{tabular}{|c|c|c|}
\hline Analytical parameter & Present method & literature method (7) \\
\hline$\lambda \max (\mathrm{nm})$ & 605 & 513 \\
\hline Temp $\mathrm{C}^{\circ}$. & Room temperature & Room temperature \\
\hline$\overline{\mathrm{pH}}$ & Basic medium & Basic medium \\
\hline Type of reaction & coupling & Diazo-coupling \\
\hline Reagent & $\begin{array}{l}\text { 2,6-dichloroquinone-4- } \\
\text { chloroimide }\end{array}$ & $\begin{array}{l}\text { Diazotized p- } \\
\text { nitroaniline }\end{array}$ \\
\hline Beer's law range $\left(\mu \mathrm{g} . \mathrm{ml}^{-1}\right)$ & $0.04-16$ & 0.04-12 \\
\hline Molar absorptivity (l.mol $\left.{ }^{-1} \mathrm{~cm}^{-1}\right)$ & 18430 & 24800 \\
\hline Color of the dye & Blue & Pinkish - red \\
\hline Composition of the dye & $1: 1$ & $1: 1$ \\
\hline Analytical application & $\begin{array}{l}\text { Pharmaceutical } \\
\text { preparations }\end{array}$ & $\begin{array}{l}\text { Pharmaceutical, oil } \\
\text { and waters }\end{array}$ \\
\hline
\end{tabular}

\section{CONCLUTION}

DCQ is a sutiable chromogenic reagent for the determination of thymol in pure form or in its pharmaceutical preparations. The suggested method is simple, time saving, sensitive and reproducible.

\section{REFERENCES}

1) Sasso M. D.; Culici M.; Braga P. C.; Guffanti E. E. and Mucci M., J. of Essential Oil Research, 18, 455-461, (2006).

2) Katzung B. G., "Basis and clinical pharmacology", $4^{\text {th }}$ Edn., Prentice Hall International Inc., London, pp.614-615, (1989).

3) Neidle E. A. and Yagida J. A., "Pharmacology and therapeutics for dentistry", $3^{\text {rd }}$ Edn., The C. V. Mosby Company, Philadelphia, pp.613621, (1989).

4) Al-Esuwati F. M., M.Sc. Thesis, Mosul University, (2002).

5) Mohammad I. Kh., J. Edu. Sci., 17(2), 41 - 49, (2005). 
6) Rodrigues L. A., Romero J.S.E. and Tena L. E., J.AOAC .International, 82, 937-947, (1999).

7) Bashir W. A. and Mansour S. S., Raf . J. Sci., 18, 28- 37, (2007).

8) $\mathrm{Al}$ - Hafith H. A. S., M. Sc. Thesis, Mosul University, (2005).

9) Thompson D. R. and Carlson M., J. Pharm.Biomed.Anal.,7, 1199-1206, (1989).

10) Nozal M. J., Bernal J. L., Jimenez J. J., Gonzalez M. J. and Higes M., J. Chromatogr. A, 954, 207-215, (2002).

11) Kohlert C., Abel G., Schmid E. and Veit M., J. Chromatogr. B, 767, 1118, (2002).

12) Belal F., Analyst, 109, 615-618, (1984).

13) Sankar D. G., Sastry C. S. P., Reddy M. N. and Prasad S. N. R., Indian J. Pharm. Sci., 49, 69-71, (1987).

14) Li S., Zheng T., Xu B. and Zhao F., Guang Pu Xue Yu, 18(4), 496-499, (1998).

15) Mohamed G. G., Khalil S. M., Zayed M. A. and El-Shall M., J. Pharm. Biomed. Anal., 28, 1127-1133, (2002) .

16) Tanabe S., Ise C., Kosugi T. and Kawanabe K., Anal. Sci., 5, 43-47, (1989).

17) "Standard methods for the examination of water and wastewater " $14^{\text {th }}$ Edn., American Public Health Association Washington, p 582 (1975). 